\title{
GAMBARAN SYMPTOMS PADA PEREMPUAN DENGAN KANKER GINEKOLOGI
}

\author{
Nunung Nurhayati, Fitriani Miraz, Astri Mutiar, Linlin Lindayani* \\ STIKep PPNI Jawa Barat, Bandung, Jawa Barat, Indonesia \\ *E-mail: linlinlindayani@gmail.com
}

\begin{abstract}
ABSTRAK
Latar belakang: Kanker ginekologi merupakan salah satu masalah kesehatan reproduksi jenis kanker yang sering terjadi. Faktor yang menyebabkan tingginya angka kejadian kanker ginekologi, yaitu banyaknya gejala-gejala yang diabaikan sehingga gejala yang sebenarnya dapat ditangani lebih awal menjadi penyakit yang sangat serius. Perempuan dengan kanker ginekologi memiliki beban gejala dari waktu ke waktu yang dapat menghasilkan respon negatif pada fisik, psikologis dan emosional pasien. Penelitian ini akan melihat beban gejala pada kanker ginekologi baik yang sudah melakukan proses kemoterapi maupun yang belum melakukan proses kemoterapi.Tujuan: Mendeskripsikan symptom pada perempuan dengan kanker ginekologi. Metode: Penelitian ini menggunakan desian penelitian kuantitatif bersifat deskriptif dengan pendekatan cross-sectional study dengan jumlah sampel 95. Instrument MSAS digunakan untuk pengukuran gejala. Data dianalisis dengan menggunakan deksriptif analisis. Hasil: Sepuluh gejala yang umum dialami responden dengan kanker ginekologi adalah merasa khawatir 96,8\% (92), merasa sedih 95,8\% (91), susah tidur 93,7\% (89), masalah dalam aktivitas atau gairah seksual 89,5\% (85), merasa lelah 86,3\% (82), kurang nafsu makan 81,1\% (77), pusing $80 \%$ (76), mudah marah 80\% (76), nyeri 78,9\% (75), kurang energi 78,9 (75), dengan rata-rata gejala sebesar 1,08 $( \pm 0,386)$. Kesimpulan: Tiga gejala yang umum dialami responden dengan kanker ginekologi adalah merasa khawatir, merasa sedih, susah tidur. Hasil penelitian ini dapat menjadi masukan bagi tenaga kesehatan untuk membuat suatu intervensi priotitas untuk meminimilkan gelaja yang dirasakan oleh pasien dengan kanker ginekologi.
\end{abstract}

Kata Kunci: Kanker Ginekologi, Gejala, Perempuan

\section{Symptom in Women with Gynecological Cancer}

\section{ABSTRACT}

Background: Gynecological cancer is one of the most common types of reproductive health problems in cancer. Factors that cause high rates of gynecological cancer, namely the number of symptoms that are ignored so that the actual symptoms can be treated early into a very serious disease. Women with gynecological cancer have a burden of symptoms over time which can produce negative responses to the physical, psychological and emotional patient. This study will look at the symptoms in gynecological cancers both those who have undergone chemotherapy and those who have not yet taken chemotherapy. Objectives: Describe the symptom burden in women with gynecological cancer. Methods: This study used a descriptive quantitative research design with a cross-sectional study approach with a sample size of 95 . The MSAS instrument was used to measure symptoms. A descriptive statistics were used to analyse the data. Results: Ten common symptoms experienced by respondents with gynecological cancer were feeling worried 96.8\% (92), feeling sad 95.8\% (91), insomnia 93.7\% (89), problems in activity or sexual arousal 89, 5\% (85), feeling tired 86.3\% (82), lack of appetite $81.1 \%$ (77), dizziness $80 \%$ (76), irritability 80\% (76), pain 78.9\% (75), less energy is 78.9 (75), with an average symptom of 1.08 ( \pm 0.386). Conclusion: Three common symptoms experienced by respondents with gynecological cancer are feeling worried, feeling sad, insomnia. The results of this study can be input for health workers to make a priority intervention to minimize the symptoms felt by patients with gynecological cancer.

Keywords: Gynecological Cancer, Symptoms Burden, Women 


\section{LATAR BELAKANG}

Kanker ginekologi merupakan salah satu masalah kesehatan reproduksi yang sering terjadi. WHO (2016) menyatakan pada tahun 2030 diprediksi akan terjadi peningkatan angka kejadian penderita kanker ovarium sebanyak $70 \%$ berada pada negara-negara berkembang, termasuk Indonesia (Perez, dkk, 2015). Berdasarkan estimasi Global Burden of Cancer, International Agency for Research on Cancer (IARC) tahun 2012, kanker serviks dan kanker ovarium merupakan kanker ginekologi yang paling sering terjadi di Indonesia. Insiden kanker serviks yaitu $17,3 \%$ per 100.000 perempuan per tahun dan kanker ovarium sebesar $8,4 \%$ per 100.000 perempuan pertahun (Ferlay, dkk, 2014). Pada tahun 2002 terdapat $80 \%$ kanker serviks menyebabkan kematian sedangkan pada tahun 2008 sekitar $88 \%$ dan kemungkinan pada tahun 2030 akan meningkat menjadi 98\% (WHO, 2016).

Faktor yang menyebabkan tingginya angka kejadian kanker ginekologi salah satunya adalah kurangnya informasi tentang kesehatan reproduksi, karena para wanita masih sangat malu dan tertutup untuk berkonsultasi secara langsung mengenai kesehatan reproduksi. Banyaknya gejala yang diabaikan sehingga gejala-gejala yang sebenarnya dapat ditangani lebih awal menjadi penyakit yang sangat serius (Munti, 2005). Gejala umum yang ditimbulkan penderita kanker serviks yaitu munculnya rasa sakit dan pendarahan saat berhubungan seksual, keputihan berlebihan serta pendarahan abnormal di luar siklus menstruasi (Ariani, 2015).

Symptom dapat didefinisikan sebagai prevalensi, frekuensi, dan keparahan gejala yang subjektif dan kuantitatif, yang menempatkan beban fisiologis pada pasien dan dapat menghasilkan respon negatif pada fisik, psikologis, dan emosional pasien (Gapstur, 2007). Perempuan dengan kanker ginekologi memiliki symptom dari waktu ke waktu, beberapa data menujukkan bahwa kelelahan, keterbatasan kognitif, depresi, kecemasan, masalah tidur, rasa sakit dan kesulitan melakukan hubungan seksual yang berlangsung selama proses pengobatan (Harrington, Hansen, \& Moskowitz, 2010). Beberapa peneliti melaporkan adanya reaksi emosional spesifik terhadap perempuan dengan kanker ginekologi, dan telah menemukan bahwa beban stress psikologis merupakan masalah yang sering dijumpai. Emosi-emosi yang dapat ditimbulkan seperti gejala depresi karena ketidakpastian hidup dan keraguan mengenai masa depan, kecemasan, kebingungan, kemarahan karena kehilangan fungsi reproduksi dan peluang untuk mempunyai keturunan, perasaan bersalah karena aktivitas seksual yang terganggu (Berek \& Jonathan, 2005). Terlepas dari berbagai jenis kanker ginekologi yang terjadi, pasien dengan kanker ginekologi merupakan permasalahan yang sering terjadi dan memiliki jumlah gejala tertinggi diantara semua kelompok kanker (Deshields, dkk, 2013). Analisis symptom dari suatu penyakit dilakukan bertujuan untuk mengukur dampak gabungan dari beban fatal yang menyebabkan kematian dan beban tidak fatal yang merugikan kesehatan.

Penelitian sebelumnya berfokus pada symptom yang muncul setelah dilakukan proses kemoterapi pada pasien dengan kanker ginekologi. Symptom yang terlihat saat didiagnosis penyakit terkait kanker ginekologi jarang diperhatikan. Di Indonesia belum ada yang meneliti mengenai symptom terkait kanker ginekologi, sedangkan symptom dalam kanker ginekologi penting untuk diperhatikan karena gejala yang menimbulkan distress dapat menurunkan kualitas hidup pasien dan menyebabkan kesulitan dalam beraktivitas sehari-hari. Penelitian ini bertujuan untuk mengetahui 
gambaran symptom pada perempuan dengan kanker ginekologi.

\section{METODE}

Penelitian ini menggunakan desain penelitian kuantitatif bersifat deskriptif dengan pendekatan cross-sectional study dimana variabel pada objek penelitian diukur pada waktu bersamaan untuk melihat gambaran symptom pada kanker ginekologi. Penelitian ini dilaksanakan di Rumah Singgah Kota Bandung pada Mei-Juni 2019.

Populasi pada penelitian ini adalah pasien dengan kanker ginekologi yang berada di Rumah Singgah di Bandung. Convenience sampling digunakan untuk teknik pengambilan sampel dengan kriteria inklusi perempuan $>18$ tahun dengan kanker ginekologi dan mengerti Bahasa Indonesia. Kriteria ekslusi pada penelitian ini yaitu perempuan dengan kanker ginekologi yang memiliki gangguan mental. Estimasi ukuran sampel dihitung menggunakan G-Power Software Versi 3.1.9.2 menggunakan exactProportion: Difference from constant (binomial test, one sample case) dengan asumsi $\alpha=0,05$, effect size $=0,15$ power level $=0,95$, constant proportion 0,65 , dengan hasil 95 sample size.

Instrumen yang digunakan dalam penelitian ini adalah The Memorial Symptom Assessment Scale (MSAS) yang dikembangkan oleh Portenoy pada tahun 1994 dengan Cronbach $\alpha=0,88$ dan 0,83. MSAS adalah instrumen yang dikembangkan untuk memberikan informasi multidimensi (kehadiran gejala, frekuensi, intensitas, distres terkait gejala). MSAS memiliki tiga subskala, yaitu Subscale Gejala Fisik (PHYS), Subscale Gejala Psikologis (PSYCH), dan Indeks Gejala Global (GSDI). GSDI adalah ukuran yang berguna secara klinis dari tekanan global berdasarkan sepuluh gejala psikologis dan fisik yang dipilih yang dianggap paling mewakili status klinis pasien. Tiga dimensi dipilih sebagai potensi yang relevan untuk evaluasi gejala; (1) tingkat keparahan gejala; (2) frekuensi terjadinya; dan (3) gangguan yang ditimbulkannya. Skala Likert 4 atau 5 titik yang terpisah dibuat untuk masingmasing dimensi ini.

MSAS versi Indonesia sudah dikembangkan dan divalidasi oleh Haryani, dkk (2018) tanpa perubahan dari versi aslinya untuk mengukur prevalensi gejala, karakteristik, dan kesusahan. Instrumen ini diterjemahkan dengan melalui dua prosedur yang terdiri dari terjemahan forward-backward dan dilakukan validasi. Proses validasi termasuk pra-pengujian melibatkan 34 pasien kanker dan pengujian psikometrik MSAS Versi Indonesia (MSAS-I) melibatkan 207 pasien kanker. Konsistensi internal, reliabilitas tes-tes ulang, konstruk, dan validitas bersamaan dari MSAS-I telah ditetapkan. Koefisien alpha Cronbach untuk skala total dan subskala MSAS-I berkisar antara 0,75 hingga 0,87 . Uji validitas Koefisien Cronbach a untuk skala total dan subskala MSAS-I=0,75-0,87. Untuk reliabilitas tes ulang $=0,80-0,89$. MSAS-I menyajikan skala yang valid dan dapat dipakai untuk menilai frekuensi gejala, tingkat keparahan, dan kesusahan di antara pasien dengan kanker dan pasien dengan penyakit medis lanjut di Indonesia.

Peneliti membuat surat pengantar dari STIKep PPNI Jawa Barat untuk Rumah Singgah di Kota Bandung; selanjutnya mengajukan surat terkait perijinan penelitian di Rumah Singgah Kota Bandung; peneliti menunggu surat balasan dari rumah singgah. Selain itu, izin etik sudah diperoleh sebelum proses perizinan penelitian yang dapatkan dari institusi afiliasi dalam penelitian ini. Peneliti melengkapi administrasi perihal perijinan penelitian, setelah adanya balasan surat dari rumah singgah; peneliti meminta ijin penelitian kepada penanggung jawab 
rumah singgah untuk melakukan penelitian, kontrak waktu penelitian sesuai dengan jam kerja rumah singgah, setelah memperoleh ijin penelitian dari pihak penanggung jawab rumah singgah, peneliti mulai melakukan penelitian. Peneliti memilih responden dengan kanker ginekologi yang datang ke rumah singgah sesuai dengan kriteria inklusi; penelitian dilaksanakan pagi hari pada pukul 09.00 WIB hingga pukul 17.00 WIB, dimana peneliti melihat daftar singgah pasien dengan kanker ginekologi maka peneliti menjelaskan tentang penelitian ini kepada responden, dan apabila responden bersedia maka responden memberikan persetujuan dan selanjutnya peneliti memberikan kuesioner kepada responden. Peneliti mendampingi responden saat pengisian kuesioner, apabila ada pertanyaan yang tidak dimengerti responden dapat bertanya lebih lanjut kepada peneliti untuk menjelaskannya. Setelah responden selesai mengisi kuesioner, kuesioner akan diperiksa oleh peneliti.

Analisis data dilakukan dengan menggunakan Statistical Package for the Social Science (SPSS) versi 25.0 untuk windows. Analisis univariat dilakukan untuk menjelaskan varibel yang diteliti dengan deskriptif analisis yaitu distribusi frekuensi, mean dan standar deviasi.

\section{HASIL}

\section{Karakteristik responden}

Berdasarkan tabel 1, lebih dari setengah responden dengan kanker ginekologi berusia 40-60 tahun, yaitu 63,2\% (60) dengan ratarata usia $44,0( \pm 7,87)$. Tingkat pendidikan responden yang paling banyak adalah SD sebesar $51,6 \%$ (49). Mayoritas pekerjaan responden adalah IRT (Ibu Rumah Tangga) sebesar $90,5 \%$ (86). Seluruh responden dalam penelitian ini sudah menikah (100\%). Jenis kanker yang banyak dialami responden yaitu kanker serviks $66,3 \%$ (63), kemudian kanker ovarium $29,5 \%$ (28), dan kanker endometrium $4,2 \%$ (4). Sekitar $46,3 \%$ (44) responden berada pada stadium III dan sebesar $63,2 \%$ (60) responden sedang dalam proses kemoterapi.

\section{Gejala, Frekuensi, Tingkat Keparahan}

Kehadiran gejala dalam penelitian ini merupakan 10 beban gejala tertinggi dengan frekuensi, tingkat keparahan gejala dan kesusahan yang sering dialami oleh responden dari keseluruhan gejala yaitu sebanyak 32 gejala. Tabel 2 menunjukkan bahwa 10 prevalensi gejala tertinggi yang dialami oleh responden berkisar dari $78,9 \%$ (76) untuk masalah nyeri hingga 96,8\% (92) yang merasa khawatir. Sepuluh gejala yang umum dialami responden adalah merasa khawatir 96,8\% (92), merasa sedih 95,8\% (91), susah tidur $93,7 \%$ (89), masalah dalam aktivitas atau gairah seksual $89,5 \%$ (85), merasa lelah $86,3 \%$ (82), kurang nafsu makan $81,1 \%$ (77), pusing $80 \%$ (76), mudah marah $80 \%$ (76), nyeri 78,9\% (75), kurang energi 78,9 (75). Dari total skor semua gejala didapatkan rata-rata gejala sebesar $1,08( \pm 0,386)$ dengan nilai minimun 0,61 dan maksimum 2,06. 
Tabel 1. Karakteristik Demografi dan Klinis Responden ( $n=95)$

\begin{tabular}{|c|c|c|}
\hline Karakteristik & Frekuensi & Persentase (\%) \\
\hline \multicolumn{3}{|l|}{ Usia (tahun) } \\
\hline$<40$ & 31 & 32,6 \\
\hline $40-60$ & 60 & 63,2 \\
\hline$>60$ & 4 & 4,2 \\
\hline \multicolumn{3}{|l|}{ Mean (SD) $44,0(7,87)$} \\
\hline \multicolumn{3}{|l|}{ Tingkat Pendidikan } \\
\hline SD & 49 & 51,6 \\
\hline SMP & 31 & 32,6 \\
\hline SMA & 15 & 15,8 \\
\hline \multicolumn{3}{|l|}{ Pekerjaan } \\
\hline IRT & 86 & 90,5 \\
\hline Pedagang & 9 & 9,5 \\
\hline \multicolumn{3}{|l|}{ Status Pernikahan } \\
\hline Menikah & 95 & 100,0 \\
\hline \multicolumn{3}{|l|}{ Jenis Kanker } \\
\hline Kanker Serviks & 63 & 66,3 \\
\hline Kanker Ovarium & 28 & 29,5 \\
\hline Kanker Endometrium & 4 & 4,2 \\
\hline \multicolumn{3}{|l|}{ Stadium Kanker } \\
\hline 1 & 8 & 8,4 \\
\hline II & 38 & 40,0 \\
\hline III & 44 & 46,3 \\
\hline IV & 5 & 5,3 \\
\hline \multicolumn{3}{|l|}{ Status Kemoterapi } \\
\hline Ya & 60 & 63,2 \\
\hline Tidak & 35 & 36,8 \\
\hline
\end{tabular}

Tabel 2. Kehadiran Gejala, Frekuensi, Tingkat Keparahan dan Kesusahan 10 Gejala dengan Prevalensi Tertinggi dari 32 Gejala $(n=95)$

\begin{tabular}{|c|c|c|c|c|c|c|c|c|c|c|c|c|c|c|}
\hline \multirow[t]{2}{*}{ Symptom } & \multirow[t]{2}{*}{$\begin{array}{c}\text { Prevalensi } \\
\%(n)\end{array}$} & \multicolumn{4}{|c|}{$\begin{array}{c}\text { Frekuensi } \\
\%\end{array}$} & \multicolumn{4}{|c|}{$\begin{array}{c}\text { Tingkat Keparahan } \\
\%\end{array}$} & \multicolumn{5}{|c|}{$\begin{array}{c}\text { Kesusahan } \\
\% \\
\end{array}$} \\
\hline & & 1 & 2 & 3 & 4 & 1 & 2 & 3 & 4 & 0 & 1 & 2 & 3 & 4 \\
\hline $\begin{array}{l}\text { Merasa } \\
\text { khawatir }\end{array}$ & $96,8(92)$ & 14,7 & 78,9 & 2,1 & 1,1 & 47,3 & 48,4 & - & 1,1 & 49,4 & 32,6 & 8,4 & 5,3 & 1,1 \\
\hline Merasa sedih & $95,8(91)$ & 18,9 & 60,0 & 15,8 & 1,1 & 23,2 & 70,5 & 2,1 & - & 49,4 & 41,1 & 3,2 & 2,1 & - \\
\hline Susah tidur & $93,7(89)$ & 9,5 & 45,3 & 16,8 & 22,1 & 8,4 & 57,9 & 8,4 & 18,9 & 5,4 & 58,9 & 4,2 & 6,3 & 18,9 \\
\hline $\begin{array}{l}\text { Masalah dalam } \\
\text { aktivitas atau } \\
\text { gairah seksual }\end{array}$ & $89,5(85)$ & 1,1 & 5,3 & 56,8 & 26,3 & - & 38,9 & 35,9 & 14,7 & - & 13,7 & 35,8 & 33,7 & 6,3 \\
\hline Merasa lelah & $86,3(82)$ & 50,5 & 32,6 & 2,1 & 1,1 & 37,9 & 46,3 & 2,1 & - & 42,0 & 26,3 & 15,8 & 1,1 & 1,1 \\
\hline $\begin{array}{l}\text { Kurang nafsu } \\
\text { makan }\end{array}$ & $81,1(77)$ & 46,3 & 15,9 & 18,9 & - & 47,4 & 30,5 & 3,2 & - & 50,2 & 13,7 & 14,7 & 3,2 & - \\
\hline
\end{tabular}




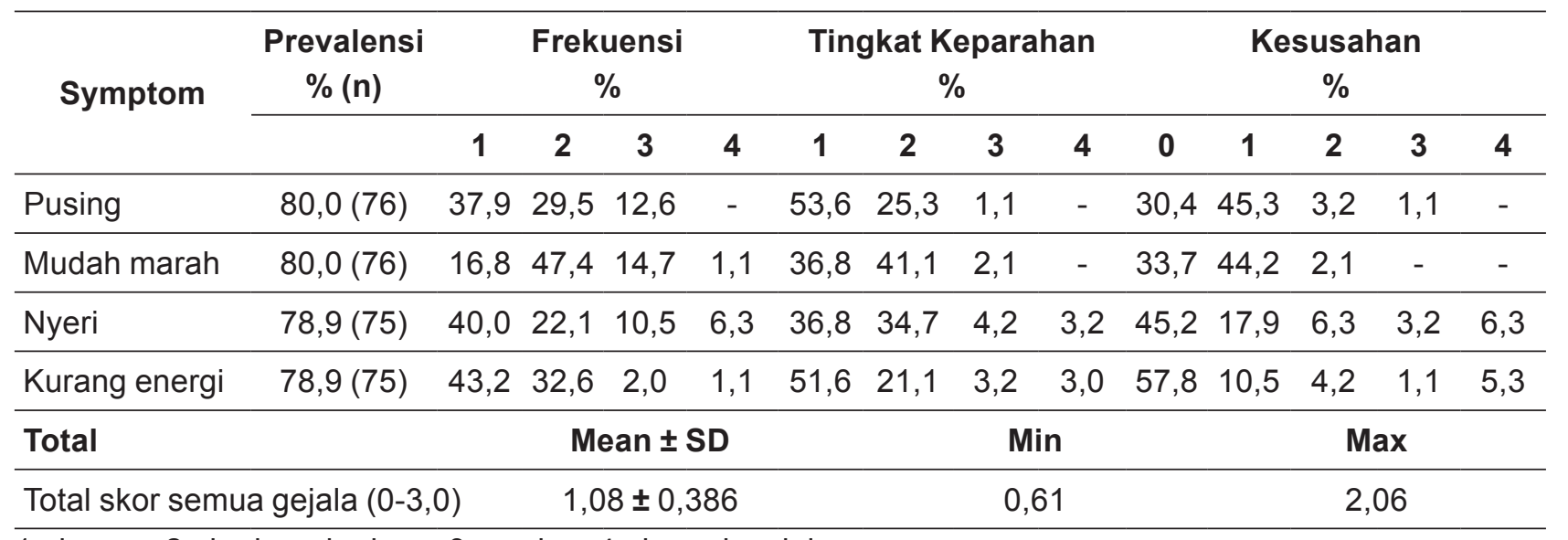

1= jarang, 2= kadang-kadang, $3=$ sering, $4=$ hampir selalu

$1=$ ringan, $2=$ sedang, $3=$ parah, $4=$ sangat parah

$0=$ tidak, $1=$ sedikit, $2=$ agak, $3=$ cukup, $4=$ sangat

\section{DISKUSI}

Keganasan ginekologi, seperti kanker serviks, endometrium dan ovarium termasuk dalam jumlah kasus kanker terbanyak pada perempuan di Indonesia. Jenis kanker ginekologi terbanyak dalam penelitian ini adalah kanker serviks $66,3 \%$ (63) dan kanker ovarium 29,5\% (28). Data menurut Cancer Country Profiles Indonesia, prevalensi kanker ginekologi yang sering terjadi pada wanita adalah kanker serviks sebanyak 20.928 jiwa dengan mortalitas $10,3 \%$ yang merupakan kasus terbanyak kedua dan kanker ovarium sebanyak 10.238 jiwa dengan mortalitas sebanyak $7,6 \%$ yang merupakan kasus terbanyak menempati urutan keempat di Indonesia (WHO, 2016).

Seluruh responden kanker ginekologi dalam penelitian ini menunjukkan bahwa 10 prevalensi gejala tertinggi yang dialami oleh responden berkisar dari 78,9\% (76) untuk masalah nyeri hingga 96,8\% (92) yang merasa khawatir. Sepuluh gejala yang umum dialami responden dengan kanker ginekologi adalah merasa khawatir $96,8 \%$ (92), merasa sedih 95,8\% (91), susah tidur $93,7 \%$ (89), masalah dalam aktivitas atau gairah seksual $89,5 \%$ (85), merasa lelah $86,3 \%$ (82), kurang nafsu makan $81,1 \%$ (77), pusing $80 \%$ (76), mudah marah $80 \%$
(76), nyeri $78,9 \%$ (75), kurang energi 78,9 (75).

Seperti penelitian yang dilakukan oleh Harrington, Hansen \& Moskowitz (2010), perempuan dengan kanker ginekologi memiliki beban gejala dari waktu ke waktu. Beberapa data menujukkan adanya kelelahan, keterbatasan kognitif, depresi, kecemasan, masalah tidur, rasa sakit dan kesulitan melakukan hubungan seksual yang berlangsung selama proses pengobatan. Gejala lebih parah terjadi pada pasien yang menerima pengobatan kanker aktif dan prevalensi gejala meningkat dengan peningkatan stadium penyakit pada kanker ginekologi.

Beberapa peneliti juga melaporkan adanya reaksi emosional spesifik terhadap perempuan dengan kanker ginekologi dan telah menemukan bahwa beban stress psikologis merupakan masalah yang sering dijumpai. Emosi-emosi yang dapat ditimbulkan seperti gejala depresi karena ketidakpastian hidup dan keraguan mengenai masa depan, kecemasan, kebingungan, kemarahan karena kehilangan fungsi reproduksi dan peluang untuk mempunyai keturunan, perasaan bersalah karena aktivitas seksual yang terganggu (Berek \& Jonathan, 2005). 
Dalam penelitian Cleeland \& Reyyes (2002), gejala dapat berasal dari penyakit itu sendiri atau akibat pengobatan/ perawatan dari suatu penyakit. Gill, Chakraborty, \& Selby (2012), dalam hasil penelitian kualitatifnya melaporkan bahwa pasien mengatakan dampak hidup dengan gejala yang parah dalam definisi mereka merupakan "beban gejala". Mereka berbicara tentang dampaknya bahwa gejalagejala yang tidak terkontrol memiliki fungsi dan jumlah emosi dari gejala-gejala yang parah. Pasien menyatakan bahwa mereka memiliki kekhawatiran khusus tentang kematian/perkembangan penyakitnya.

Penelitian ini mempunyai keterbatasan dalam hal jumlah responden yang sedikit, metode pengumpulan data dalam penelitian ini dengan pengisian kuesioner yang membutuhkan waktu cukup lama yaitu lebih dari 10 menit, sehingga memungkinkan responden mengalami kelelahan dalam pengisian kuesioner.

\section{SIMPULAN}

Sepuluh gejala yang umum dialami responden dengan kanker ginekologi adalah merasa khawatir, merasa sedih, susah tidur, masalah dalam aktivitas atau gairah seksual, merasa lelah, kurang nafsu makan, pusing, mudah marah, nyeri, dan kurang energi. Dari total skor semua gejala didapatkan rata-rata gejala sebesar 1,08 $( \pm 0,386)$ dengan nilai minimun 0,61 dan maksimum 2,06. Hasil penelitian ini dapat menjadi masukan bagi tenaga kesehatan untuk membuat suatu intervensi priotitas untuk meminimilkan gelaja yang dirasakan oleh pasien dengan kanker ginekologi

\section{DAFTAR PUSTAKA}

Ariani, S. (2015). STOP! KANKER. Yogyakarta: Istana Media

Berek \& Jonathan, S. (2005). Psychological Issues, Practical Gynecologic
Oncology. Philadelphia: Lippincott \& Wilkins.

Cleeland, C. S., \& Reyyes, C. C. (2002). When is it Justified to Treat Symptoms? Measuring Symptom Burden. Cancer Network, 16(9): 1-7.

Deshields, T. L., Potter, P., Olsen, S., \& Liu, J. (2013). The persistence of symptom burden: symptom experience and quality of life of cancer patients across one year. Support Care cancer, 22(4): 10891096. Doi: 10.1007/s00520-0132049-3.

Ferlay, J., Soerjomataram, I., Ervik, M., Dikshit, R., Eser, S., Mathers, C., . . . Bray, F. (2014). Cancer Incidance and Mortality Worldwide: Sources, methods, and major pattern in GLOBOCAN 2012. International Journal of Cancer, 136(5): E359-E386. Doi: 10.1002/ijc.29210.

Gapstur, R. L. (2007). Symptom Burden: A Concept Analysis and Implications for Oncology Nurses. Oncology Nursing Forum, 34(3): 673-680. Doi: 10.1188/07.onf.673-680

Gill, A., Chakraborty, A., \& Selby, D. (2012). What is Symptom Burden: A Qualitative exploration of Patient Definitions. Journal of Palliative Care, 28(2): 83-89. doi:10.1177/082585971202800204

Harrington, C., Hansen, J., \& Moskowitz, M. (2010). it's not over when it's over: long-term symptoms in cancer survivors- a systematic rewiew. International Journal Psychological Med, 40(2): 163-181. Doi: 10.2190/ pm.40.2.c

Haryani, Hsu, Y.-Y., Warsini, S., \& Wang, S.T. (2018). Measuring the Symptom Experience of Patients with Cancer in Indonesia: Cross-cultural Adaptation and Validation of the 
Memorial Symptom Assessment Scale Indonesian Version. Journal of Pain and Symptom Management, 50(6): 920-927. doi:10.1016/j. jpainsymman.2018.08.01

Munti, R. B. (2005). Demokrasi Keintiman: Seksualitas Di Era Global. Yogyakarta: LKiS.

Perez, O. R., Magrina, J., Garcia, T., \& Zo, A. (2015). Propphylatic Salpingektomy and High grade serous Epitheleal Carcinoma a Riappriasal. Journal Surgical Oncology, 24(4): 335-344. Doi: 10.1016/j.suronc.2015.09.008.
Portenoy, R. K., Thaler, H. T., Kornblith, A. B., McCarthy Lepore, J., FriedlanderKlar, H., Kiyasu, E., ... Scher, H. (1994). The Memorial Symptom Assessment Scale: an instrument for the evaluation of symptom prevalence, characteristics and distress. European Journal of Cancer, 30(9): 1326-1336. doi:10.1016/0959-8049(94)90182-1

WHO. (2016). Comprehensive Cervical Cancer Control. A Guide to Essential Practice. Geneva: World Health Organization. 